\title{
Verruciform xanthoma of the esophagus: an uncommon entity in an unusual site
}

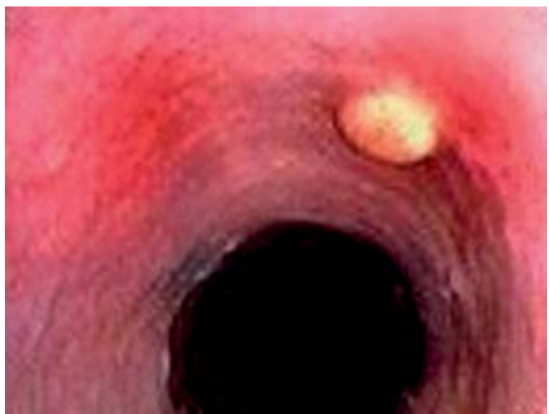

Fig. 1 Esophagogastroscopy showing a small, elevated, granular/verrucoid pink-yellowish lesion, $3 \mathrm{~mm}$ in diameter, in the mucosa of the upper third of the esophagus.

A 49-year-old man was admitted for medical examination because of epigastric discomfort. Esophagogastroscopy revealed a small, elevated, verrucoid pink-yellowish mucosal lesion, $3 \mathrm{~mm}$ in diameter, in the upper third of the esophagus ( $\bullet$ Fig. 1).

Low power histological examination revealed an exophytic lesion resembling a squamous papilloma, with the typical papillomatosis, acanthosis, and hyperparaker- atosis of the esophageal squamous epithe$\operatorname{lium}(\bullet$ Fig. 2a).

At higher magnification, neutrophilic intraepithelial exocytosis was observed, and the subepithelial connective tissue appeared infiltrated by clear cells with foamy cytoplasm and small nuclei with no atypia ( Fig. 2b,c). At immunohistochemistry, the foamy cells were negative for cytokeratins, s-100 protein, and CD1a, while CD68 was strongly positive ( $\mathbf{F i g} \mathbf{2} \mathbf{d}$ ), indicating the histiocytic nature of the cells. The histological and immunohistochemical features allowed making a diagnosis of verruciform xanthoma of the esophagus. Verruciform xanthoma is a lesion characteristically described in the oral cavity and genital skin [1]. It is usually solitary, but cases of multifocal lesions have been reported [1]. The main histological feature is the presence of foamy histiocytes in the subepithelial stroma of a squamous epithelium displaying papillomatosis, acanthosis, and hyperkeratosis, as observed in papillomatous/verrucous lesions. Intraepithelial neutrophilic infiltration is an-

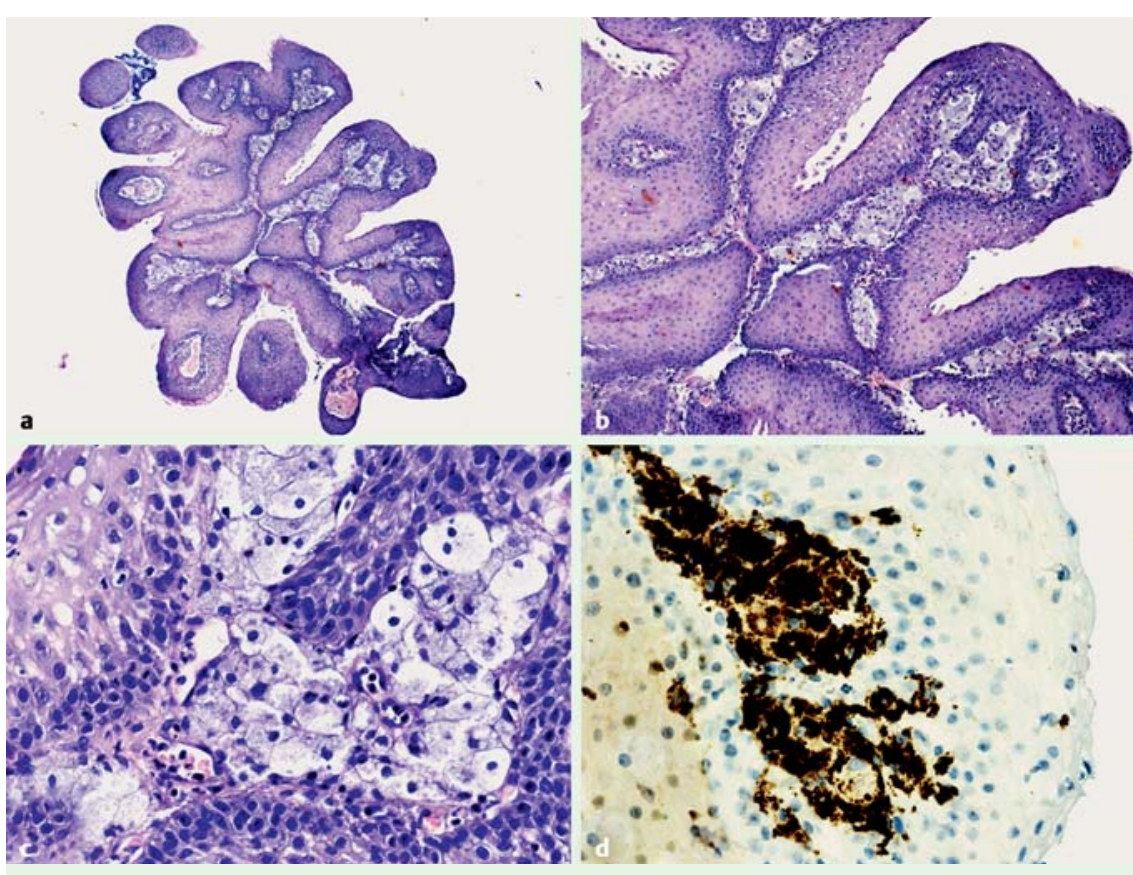

Fig. 2 a Low power histological section showing papillomatosis, acanthosis, and hyperparakeratosis of the squamous epithelium, as usually seen in squamous papilloma (hematoxylin and eosin, original magnification $\times 40$ ). b, c At higher magnification, the subepithelial connective tissue appears infiltrated by clear cells with foamy cytoplasm and small nuclei with no atypia (hematoxylin and eosin, original magnification: $\mathbf{b} \times 200$; $\times \times 400$ ). $\mathbf{d}$ There is diffuse and strong positivity for CD68 on immunostaining (original magnification $\times 400$ ). other hallmark. The etiology is still unknown, most cases being unrelated to a viral infection. The presence of human papilloma virus in the epithelial cells has been demonstrated in only two reported lesions in the oral mucosa [2] and scrotum [3]. To the best of our knowledge, our case represents the second description in the English literature of verruciform xanthoma in the esophagus [4].

\section{Competing interests: None}

Endoscopy_UCTN_Code_CCL_1AB_2AC_3AB

\section{S. Licci $^{1}$, S. M. A. Campo ${ }^{2}$, P. Ventura ${ }^{1}$}

1 Department of Pathology, Santo Spirito Hospital, Rome, Italy

2 Gastroenterology Unit, Nuovo Regina

Margherita Hospital, Rome, Italy

\section{References}

1 Shafer W. Verruciform xanthoma. Oral Surg 1971; 31: 784-789

2 Iamaroon A, Vickers $R A$. Characterization of verruciform xanthoma by in situ hybridization and immunohistochemistry. J Oral Pathol Med 1996; 25: 395-400

3 Khaskhely NM, Uezato H, Kamiyama $\mathrm{T}$ et al. Association of human papillomavirus type 6 with a verruciform xanthoma. Am J Dermatopathol 2000; 22: 447-452

4 Herrera-Goepfert R, Lizano-Soberón M, García-Perales $M$. Verruciform xanthoma of the esophagus. Hum Pathol 2003; 34: 814-815

\section{Bibliography}

DOI $10.1055 / \mathrm{s}-0030-1255944$

Endoscopy 2010; 42: E330

(c) Georg Thieme Verlag KG Stuttgart · New York . ISSN 0013-726X

\section{Corresponding author Dr. S. Licci \\ Department of Pathology Santo Spirito Hospital Lungotevere in Sassia, 1 00193 Rome \\ Italy \\ Fax: +39-06-68352491 \\ stefano.licci@hotmail.it}

